\title{
DETERMINAN KESEMPATAN KERJA PADA SEKTOR INFORMAL PERDAGANGAN DAN JASA DI KOTA AMBON
}

\author{
Arce Yulita Ferdinandus \\ Universitas Victory Sorong. \\ Email: Acheyulitafernandhez@yahoo.co.id
}

Diterima:17 April 2016. Dipublikasikan: 1 Juni 2016

\begin{abstract}
ABSTRAK
Penelitian ini bertujuan untuk menganalisis pengaruh upah, jenis usaha dan modal terhadap kesempatan kerja di Kota Ambon khususnya pada sektor informal. Penelitian ini dilakukan pada perdagangan dan jasa sektor informal di Kota Ambon. Data yang digunakan dalam penelitian ini adalah data primer. Data primer tersebut berupa data hasil penelitian dengan metode wawancara aktif. Ada juga data diperoleh dari Badan Pusat Statistik kota Ambon. Alat analisis yang digunakan dalam penelitian ini adalah analisis regresi dengan uji statistic dan uji asumsi klasik. Berdasarkan Nilai Uji Regresi telah menbuktikan bahwa variabel tingkat upah sangat berpengaruh yang positif dan signifikan terhadap kesempatan kerja, dengan begitu variabel tingkat upah yang berbanding terbalik dengan kesempatan kerja yang tersedia di Kota Ambon. Dikarenakan sektor informal memberikan peluang kerja dan pendapatan yang mencukupi kebutuhan per hari bagi setiap pekerja sehingga besar kecilnya upah yang diperoleh tidak memberikan pengaruh negatif terhadap kesempatan kerja yang tersedia. Dan untuk variabel jenis usaha dalam sektor informal khususnya perdagangan dan jasa sangat berpengaruh yang positif dan signifikan terhadap kesempatan kerja, dengan begitu kesempatan kerja sangatlah tergantung dari jenis usaha yang tersedia di Kota Ambon. Jenis usaha di Kota Ambon dalam sektor infromal berkembang pesat mendorong terciptanya kesempatan kerja. Sedangkan variabel modal usaha tidak berpengaruh secara signifikan terhadap kesempatan kerja. Dikarenakan seluruh usaha pada sektor informal pada awal memulai usaha tidak membutuhkan modal besar dalam mengembangkan usaha tidak seperti usaha - usaha pada sektor formal yang membutuhkan modal besar dengan diikuti meningkatnya penyerapan tenaga kerja, sehingga kesempatan kerja yang tersedia pada awal usaha di sektor informal tidak dipengaruhi oleh modal usaha.
\end{abstract}

\section{Kata Kunci : Upah, Jenis Usaha, Modal, Kesempatan Kerja dan Sektor Informal.}

\section{PENDAHULUAN}

Dalam era perdagangan bebas, akan tercipta suatu sistem ekonomi yang terbuka melalui mobilitas output dan faktor-faktor produksi tenaga kerja dan modal. Perdagangan luar negeri berpengaruh bagi kegiatan dan perkembangan perekonomian suatu negara, karena merupakan salah satu motor penggerak pembangunan (engine of development) terhadap laju pertumbuhan ekonomi dan sektor-sektor lainnya dalam negeri, yang akhirnya akan memperluas kesempatan kerja. Di lain pihak perdagangan bebas mempunyai implikasi yang kurang menguntungkan, bagi negara berkembang yang mempunyai tingkat efisiensi yang rendah akhirnya kalah bersaing dengan negara-negara yang memiliki efisiensi yang 
tinggi. Sehingga, dalam meningkatkan pembangunan ekonomi tidak saja tergantung pada pengembangan industrialisasi dan program-program pemerintah. Namun, tidak pula lepas dari peran sektor informal yang merupakan"katup pengaman" dalam pembangunan ekonomi. Keberadaan sektor informal tidak dapat di abaikan dalam pembangunan ekonomi. Dalam sejarah perekonomian Indonesia, kegiatan usaha sektor informal sangat potensial dan berperan dalam menyediakan lapangan pekerjaan dengan penyerapan tenaga kerja secara mandiri. Tingginya pertumbuhan penduduk dan jumlah penduduk indonesia akan menghambat pembangunan apabila tidak diimbangi dengan perluasan kesempatan kerja serta peningkatan mutu angkatan kerja.

Disisi lain, pemerintah atau swasta mempunyai kemampuan yang terbatas dalam menyediakan lapangan kerja baru. Kondisi ini membuat pemerintah berkepanjangan untuk berusaha memperluas dan menciptakan kesempatan kerja baru dalam rangka menampung pertambahan tenaga kerja guna mengurangi pengangguran,yaitu melalui pembangunan di segala sektor.

Salah satunya dengan cara memperluas kegiatan perdagangan dan jasa untuk meningkatkan penyerapan tenaga kerja dan kesempatan kerja, ini tidak terlepas dari faktor faktor yang mempengaruhinya seperti jumlah unit usaha, nilai investasi dan upah. Seiring dengan perkembangan zaman dan semakin pesatnya pertumbuhan penduduk di Indonesia khususnya di kota Ambon, semakin banyak pula penduduk yang berpindah dari desa ke kota, atau yang disebut juga dengan Urbanisasi. Rata rata bepergian ke kota yang lain, selain karena di kota merupakan pusat kegiatan perekonomian, mereka beranggapan bahwa upah di kota yang juga menjanjikan. Umumnya tujuan para migran yang berbondong-bondong ke kota tidak lain adalah untuk memperbaiki dan mencari nafkah, karena kondisi di daerah mereka secara sosial ekonomi terkadang sangat sulit untuk mencapai harapan hidup yang lebih layak. Oleh sebab itu salah satu upaya adalah merantau ke kota walaupun hanya memiliki modal tenaga saja. Namun mereka hanya bermodalkan skill dan nekat, sehingga ketika mereka sampai di Kota, mereka kesulitan untuk mencari pekerjaan.

Dari permasalahan di atas, munculah yang dinamakan Sektor Informal. Istilah "sektor informal" biasanya digunakan untuk menunjukkan sejumlah kegiatan ekonomi yang berskala kecil. Sektor informal di kota terutama harus dipandang sebagai unit-unit berskala kecil yang terlibat dalam produksi dan distribusi barang-barang yang masih dalam suatu proses evolusi dari pada dianggap seagai sekelompok perusahaan yang berskala kecil dengan masukan-masukan (inputs) modal dan pengelolaan (managerial) yang besar.

Sektor informal adalah sektor yang tidak terorganisasi, tidak teratur dan kebanyakan legal tetapi tidak terdaftar. Sektor informal memiliki karakteristik seperti jumlah unit usaha yang banyak dalam skala kecil, kepemilikan oleh individu atau keluarga, teknologi yang sederhana atau padat atau padat tenagakerja, tingkat pendidikan dan ketrampilan yang rendah, akses kelembaga keuangan daerah, produktifitas tenaga kerja yang rendah dan tingkat upah yang juga relatif lebih rendah di bandingkan sektor formal.

Penggunaan modal pada sektor informal relative lebih sedikit apabila di bandingkan dengan sektor formal sehingga cukup dengan modal sedikit sudah dapat mempekerjakan orang dengan menyediakan pelatihan dan ketrampilan, sektor informal dapat memiliki peran yang Besar dalam pengembangan sumberdaya manusia. Sektor informal memunculkan permintaan untuk tenaga kerja semi terampil dan tidak terampil.

Peran sektor informal kota sangat
strategis sebagai katup pengaman
pengangguran. Di berbagai kota besar, ketika
situasi krisis melanda Indonesia dan
pengangguran terjadi di mana-mana, maka
peluang satu-satunya yang r dapat
menyelamatkan kelangsungan hidup jutaan


Sentralisasi Volume 5(2): 1-14 (2016)

Determinan Kesempatan Kerja Pada Sektor Informal....

Arce Yulita Ferdinandus

korban PHK dan pengangguran dari desa adalah sektor informal.

Sektor informal sangat penting artinya dalam proses pembangunan dan proses modernisasi masyarakat yang sebagian besar masih bersifat tradisional atau semitradisional. Sebelum bekerja dan berusaha di sektor formal tenaga kerja dari sektor tradisional berusaha dan bekerja terlebih dahulu di sektor informal. Setelah memperoleh pengetahuan, keahlian dan pengalaman di sektor informal barulah mereka beralih dan mengalikan usahanya ke sektor formal yang bersifat modern.

Kegiatan sektor informal yang menonjol biasanya terjadi di kawasan yang padat penduduknya, Dimana pengangguran maupun pengangguran terselubung merupakan masalah yang utama dengan kenyataan seperti ini limpahan tenaga kerja tersebut masuk kedalam sektor informal, tetapi di pandang sebagai penyelesaian sementara karena di dalam sektor informal sendiri terdapat persoalan yang sangat rumit. Sektor informal memberikan kemungkinan kepada tenagakerja yang berlebihan di pedesaan untuk migrasi dari kemiskinan dan pengangguran. Sektor informal sangat berkaitan dengan sektor formal diperkotaan .Sektor formal tergantung pada sektor informal terutama dal hal input murah dan penyediaan barang-barangbagi pekerja di sektor formal. Sebaliknya sektor informal tergantung dari pertumbuhan di sektor formal. Sektor informal kadang-kadang justru mensubsidi sektor formal dengan menyediakan barang-barang dan kebutuhan dasar yang murah bagi pekerja di sektor formal.

Hal menarik yang terlihat dari perpindahan tenaga kerja dari desa ke kota adalah banyaknya tenaga kerja yang masuk ke dalam usaha kecil-kecilan di kota yang bersifat swakarya dan swadaya. Usaha kecil-kecilan ini dapat bebrbentuk usaha perdagangan seperti pedagang kaki lima, penjual bakso, asongan, dan sebagainya. Selain itu juga pada jasa pengangkutan seperti tukang becak, tukang ojek dan lain-lain; industri kecil dan rumah tangga (cottage industry dan home industry ); ataupun bentuk-bentuk usaha lainya. Usaha-usaha tersebut sering disebut sektor informal karena sifatnya yang tidak mempunyai hubungan dengan pemerintah, baik dalam hal perijinan, perpajakan maupun perlindungan.

Perilaku sektor formal yang kikir dalam penyerapan tenaga kerja itu, justru membawa dampak positif bagi sektor informal.Bagaimana tidak sector informallah yang diharapkan dapat menjadi sektor yang meyerap angka pengangguran yang cukup besar. Melihat hal seperti ini mestinya para pengambil keputusan di pemerintah menjadikan sector ini sekaligus menjadikan tantangan tersendiri untuk membalikan arah pembangunan ekonomi dari yang berorientasi pada pertumbuhan ekonomi menjadi pemerataan ekonomi namun keduanya tetap berjalan seiring.

Sektor informal sering dipandang sebagai sektor transisi bagi tenaga kerja dari sektor pertanian di desa ke sektor industri di kota. Fenomena munculnya sektor informal hanyalah bersifat temporer, akibat keterampilan yang terbatas, para pencari kerja dari desa, pada awal kepindahanya untuk sementara berusaha dan bekerj di sektor informal. Setelah mapan dan berpengalaman mereka akan mengalihkan usahanya ke sektor formal, dimana terjadi peralihan status usaha yang tadinya informal menjadi formal, dan berpindahnya pekerja yang tadinya bekerja di sektor informal ke sektor formal. Namun pada kenyataanya seringkali proses ini tidak berjalan seperti yang diharapkan. Yang terjadi adalah usaha di sektor informal khususnya industri kecil dan industri rumah tangga semakin menjamur. Demikian juga dengan jumlah pekerjanya. Tenaga kerja dari desa sebagian besar bukan diserap oleh sektor industri tetapi oleh sektor jasa.

Hal tersebut menandakan bahwa usaha yang tadinya berstatus informal tidak berubah menjadi formal. Demikian juga pekerja yang berada di sektor informal tetap berada di sektor tersebut. Dengan kata lain, sektor informal bukan menjadi sektor transisi justru menjadi sektor yang dituju oleh pencari kerja oleh sektor tradisional ( pertanian ). Selain itu juga menjadi 
Sentralisasi Volume 5(2): 1-14 (2016)

Determinan Kesempatan Kerja Pada Sektor Informal....

Arce Yulita Ferdinandus

sektor yang di tuju oleh pencari kerja pertama yang tidak tertampung di sektor formal maupun pekerja sektor formal yang tidak memperoleh penghasilan yang cukup. Sehingga secara sambilan ataupun serius merangkap berusaha dan bekerja di sektor informal dari kedua hal tersebut maka menarik untuk mengkaji bagaimana kecendrungan sektor informal di Indonesia apakah bersifat permanen ataukah temporer dan bagaimana proses formalisasi sektor informal.

Sektor informal yang berkembang dari tahun ke tahun pada provinsi Maluku khususnya Kota Ambon dapat menjadi solusi bagi tingkat pengangguran yang selalu meningkat tiap tahunnya. Walaupun dunia perekonomian terjadi krisis moneter sehingga lapangan usaha formal terjadi penurunan dalam hal pendapatan namun seluruh lapangan usaha pada sektor informal mampu bertahan dan berkembang ditengah - tengah kemerosotan pembangunan perekonomian.

\section{Pengertian Tenaga Kerja}

Menurut UU No. 25 Tahun 1997 tentang ketentuan-ketentuan pokok ketenaga kerjaan disebutkan bahwa tenaga kerja adalah setiap seorang laki-laki ataupun perempuan yang sedang mencari pekerjaan baik didalam maupun diluar hubungan kerja guna menghasilkan balas jasa untuk memenuhi kebutuhan masyarakat (Mustika, $2010: 30$ ).

Tenaga kerja adalah penduduk dalam usia kerja. Dalam literatur biasanya adalah seluruh penduduk suatu Negara yang dapat memproduksi barang dan jasa tenaga kerja adalah pengertian tentang potensi yang terkandung dalam diri manusia yang dikaitkan dengan perdagangan diberbagai kegiatan atau usaha yang ada. Keterlibatan manusia yang dimaksud adalah keterlibatan unsur jasa atau tenaga kerja. Tenaga kerja merupahkan salah satu faktor produksi yang sangat penting sumber daya alam, modal dan teknologi. Ditinjau dari segi umum pengertian tenaga kerja menyangkut manusia yang mampu bekerja untuk menghasilkan barang dan jasa dan mempunyai nilai ekonomi yang dapat beragam bagi kebutuhan masyarakat secara fisik kemampuan tenaga kerja diukur dari usia.(Fadilah,2012:3).

\section{Konsep Ketenagakerjaan}

Beberapa pengertian yang berhubungan dengan ketenagakerjaan, yaitu:

(1). Tenaga kerja( manpower) Tenaga kerja adalah penduduk dalam usia kerja (berusia 1564 tahun) atau jumlah, seluruh penduduk dalam suatu Negara yang dapat memproduksi barang danjasa jika ada permintaan terhadap tenaga mereka, dan jika mereka mau berpartisipasi dalam aktivitas tersebut.

(2). Angkatan kerja (labor force) Adalah bagian dari tenaga kerja yang sesungguhnya terlibat, atau berusaha untuk terlibat, dalam kegiatan produktif yaitu produksi barang dan jasa.

(3). Tingkat partisipasi angkatan kerja (Labor force participation rate ). Adalah menggambarkan jumlah angkatan kerja dalam suatu kelompok umum sebagai presentase penduduk dalam kelompok umur tersebut.

$$
\mathrm{TPAK}=\frac{\text { Angkatankerja }}{\text { Tenagakerja }} \times 100 \%
$$

(4). Tingkat pengangguran( Unemployment rate ) Adalah angka yang menunjukan berapa banyak dari jumlah angkatan kerja yang sedang aktif mencari pekerjaan.Pengertian menganggur di sini adalah aktif mencari pekerjaan.

$\mathrm{TP}=\frac{\text { JumlahOrangyangMencariPekerjaan }}{\text { JumlahAngkatankerja }} \times 100 \%$

(5). Pengangguran terbuka ( Open Unemployment ) Pengangguran terbuka atau pengangguran adalah bagian dari angkatan kerja yang sekarang ini tidak bekerja dan sedang aktif mencari pekerjaan.

(6). Setengah menganggur ( Underemployment ) Adalah perbedaan antara jumlah pekerjaan yang betul dikerjakan seseorang dalam pekerjaannya dengan jumlah pekerjaan yang secara normal mampu dan ingin dikerjakannya. 
Sentralisasi Volume 5(2): 1-14 (2016)

Determinan Kesempatan Kerja Pada Sektor Informal....

Arce Yulita Ferdinandus

(7). Setengah Menganggur yang Kentara (Visible Undereemployment ) Adalah jika seseorang bekerja tidak tetap ( part time) di luar keinginanya sendiri, atau bekerja dalam waktu yang lebih pendek dari biasanya.

(8). Setengah Menganggur yang Tidak Kentara ( Invisible Underemployment) Adalah jika seseorang bekerja secara penuh ( full time ) tetapi pekerjaanya itu dianggap tidak mencukupi, karena pendapatanya yang terlalu rendah atau pekerjaan tersebut tidak memungkinkan ia untuk mengembangkan seluruh keahliannya.

(9). Pengangguran tidak kentara ( Disguised Unemployment ). Dalam angkatan kerja mereka dimasukan dalam kegiatan bekerja, tetapi sebetulnya mereka adalah penganggur jika dilihat dari segi produktivitasnya. Misalnya: pekerjaan yang seharusnya dikerjakan dua orang, tetapi dikerjakan oleh tiga orang sehingga satu orang merupakan disguised unemployment.

(10). Pengangguran Friksional Adalah pengangguran yang terjadi akibat pindahnya seseorang dari suatu pekerjaan ke pekerjaan yang lain, dan akibatnya harus mempunyai tenggang waktu dan berstatus sebagai penganggur sebelum mendapatkan pekerjaan yang lain tersebut.

(11). Pengangguran Struktural Adalah pengangguran yang disebabkan karena ketidakcocokan antara struktur para pencari kerja sehubungan dengan ketrampilan, bidang keahlian, maupun daerah lokasinya dengan struktur permintaan tenaga kerja yang belum terisi ( Mulyadi,2003 : 59 ). Keadaan tenaga kerja di Indonesia sangat dipengaruhi oleh pertumbuhan penduduk. Semakin besar jumlah penduduk usia kerja, maka secara otomatis jumlah angkatan kerja akan bertambah. Bila peningkatan angkatan kerja seiring dengan bertambahnya penduduk yang bekerja, hal ini dapat berarti peningkatan Tingkat Partisipasi Angkatan Kerja (TPAK) diiringi dengan menurunnya partisipasi penduduk yang bekerja ini pertanda bahwa pemicu tingginya TPAK adalah meningkatnya penduduk yang mencari pekerjaan. Dengan kata lain mengakibatkan bertambahnya pengagguran.

\section{Kesempatan Kerja.}

Kesempatan kerja adalah banyaknya orang yang dapat tertampung untuk bekerja pada suatu perusahaan atau suatu instansi (Disnakertrans, 2002). Kesempatan kerja ini akan menampung semua tenaga kerja yang tersedia apabila lapangan pekerjaan yang tersedia mencukupi atau seimbang dengan banyaknya tenaga kerja yang tersedia. Kebijaksanaan negara dalam kesempatan kerja meliputi upaya-upaya untuk mendorong pertumbuhan dan perluasan lapangan kerja di setiap daerah serta, perkembangan jumlah dan.kualitas angkatan kerja yang tersedia agar dapat memanfaaatkan seluruh potensi pembangunan di daerah masing-masing.

Kesempatan kerja sebagai lapangan usaha atau kesempatan kerja yang tersedia untuk bekerja akibat dari suatu kegiatan ekonomi, dengan demikian kesempatan kerja mencakup lapangan pekerjaan yang sudah diisi dan kesempatan kerja juga dapat diartikan sebagai partisipasi dalam pembangunan. (Sagir ,1994 : 52)

Dari definisi di atas, maka kesempatan kerja apat dibedakan menjadi dua golongan yaitu:

1. Kesempatan kerja permanen yaitu kesempatan kerja yang memungkinkan orang bekerja secara terus-menerus sampai mereka pensiun atau tidak mampu lagi untuk bekerja. Misalnya adalah orang yang bekerja pada instansi pemerintah atau swasta yang memiliki jaminan sosial hingga hari tua dan tidak bekerja ditempat lain.

2. Kesempatan kerja temporer yaitu kesempatan kerja yang memungkinkan seseorang bekerja dalam waktu yang relatif singkat, kemudian menganggur untuk menunggu kesempatan kerja baru. Misalnya adalah orang yang bekerja sebagai pegawai lepas pada perusahaan swata dimana pekerja mereka tergantung order. 


\section{Upah}

Masalah yang timbul dalam hal pengupahan berhubungan dengan berbagai sistem pengupahan yangh diterapkan. Sitem pengupahan merupakan kerangka bagaimana upah diatur dan ditetapkan. Sistem pengupahan di Indonesia pada umumnya didasarkan kepada tiga fungsi upah, (Simanjuntak,2001 : 125) yaitu:

(1) menjamin kehidupan yang layak bagi pekerja dan keluarganya.

(2) Mencerminkan imbalan atas hasil kerja seseorang, dan

(3) Menyediakan insentif untuk mendorong peningkatan produktifitas kerja.

\section{Teori Upah Efisiensi}

1 . Upah yang tinggi membuat para pekerja lebih produktif. Pengaruh upah terhadap efisiensi pekerja dapat menjelaskan kegagalan perusahaan untuk memangkas upah meskipun terjadi kelebihan penawaran tenaga kerja. Meskipun akan mengurangi tagihan upah perusahaan, (jika teori ini benar) maka pengurangan upah akanmemperendah produktivitas pekerja dan laba perusahaan.

2. Upah yang tinggi menurunkan perputaran tenaga kerja. Dengan membayar upah yang tinggi, perusahaan mengurangi frekuensi pekerja yang keluar dari pekerjaan, sekaligus mengurangi waktu yang dibutuhkan perusahaan untuk menarik dan melatih pekerja baru.

3. Kualitas rata-rata tenaga kerja perusahaan bergantung pada upah yang dibayar kepada karyawannya. Jika perusahaan mengurangi upahnya, maka pekerja terbaik bisa mengambil pekerjaan di tempat lain, meninggalkan perusahaan dengan pekerja yang tidak terdidik yang memiliki lebih sedikit alternatif.

4. Upah yang tinggi meningkatkan upaya pekerja. Teori ini menegaskan bahwa perusahaan tidak dapat memantau dengan sempurna upaya para pekerja, dan para pekerja harus memutuskan harus memutuskan sendiri sejauh mana mereka akan bekerja keras, semakin tinggi upah semakin besar kerugian bagi pekerja jika mereka sampai di pecat. Dengan membayarkan upah yang lebih tinggi perusahaan memotifasi lebih banyak pekerja agar tidak bermala-malasan dan dengan demikian meningkatkan produktifitas mereka .(Mankiw, 2006 : 161)

\section{Upah Tenaga Kerja}

Pemberian upah kepada tenaga kerja dalam suatu kegiatan produksi pada dasarnya merupakan imbalan/balas jasa dari para produsen kepada tenaga kerja atas prestasinya yang telah disumbangkan dalam kegiatan produksi. Upah tenaga kerja yang diberikan tergantung pada:

1. Biaya keperluan hidup minimum pekerja dan keluarganya.

2. Peraturan undang-undang yang mengikat tentang upah minimum pekerja (UMR).

3. Produktivitas marginal tenaga kerja.

4. Tekanan yang dapat diberikan oleh serikat buruh dan serikat pengusaha.

5. Perbedaan jenis pekerjaan.

Upah yang diberikan oleh para pengusaha secara teoritis dianggap sebagai harga dari tenaga yang dikorbankan pekerja untuk kepentingan produksi. Sehubungan dengan hal itu maka upah yang diterima pekerja dapat dibedakan dua macam yaitu:

1. Upah Nominal adalah sejumlah upah yang dinyatakan dalam bentuk uang yang diterima secara rutin oleh para pekerja.

2. Upah Riil adalah kemampuan upah nominal yang diterima oleh para pekerja jika ditukarkan dengan barang dan jasa, yang diukur berdasarkan banyaknya barang dan jasa yang bisa didapatkan dari pertukaran tersebut.

\section{Teori Upah Tenaga Kerja.}

1. Teori Upah Wajar (alami) dari David Ricardo 
Sentralisasi Volume 5(2): 1-14 (2016)

Determinan Kesempatan Kerja Pada Sektor Informal....

Arce Yulita Ferdinandus

Upah menurut kodrat adalah upah yang cukup untuk pemeliharaan hidup pekerja dengan keluarganya. Di pasar akan terdapat upah menurut harga pasar adalah upah yang terjadi di pasar dan ditentukan oleh permintaan dan penawaran. Upah harga pasar akan berubah di sekitar upah menurut kodrat. Oleh ahli-ahli ekonomi modern, upah kodrat dijadikan batas minimum dari upah kerja.

2. Teori Upah Besi

Teori upah ini dikemukakan oleh Ferdinand Lassalle.Penerapan sistem upah kodrat menimbulkan tekanan terhadap kaum buruh, karena kita ketahui posisi kaum buruh dalam posisi yang sulit untuk menembus kebijakan upah yang telah ditetapkan oleh para produsen. Berhubungan dengan kondisi tersebut maka teori ini dikenal dengan istilah "Teori Upah Besi”.Untuk itulah Lassalle menganjurkan untuk menghadapi kebijakan para produsen terhadap upah agar dibentuk serikat pekerja.

3. Teori Dana Upah

Teori upah ini dikemukakan oleh John Stuart Mill. Menurut teori ini tinggi upah tergantung kepada permintaan dan penawaran tenaga kerja. Sedangkan penawaran tenaga kerja tergantung pada jumlah dana upah yaitu jumlah modal yang disediakan perusahaan untuk pembayaran upah. Peningkatan jumlah penduduk akan mendorong tingkat upah yang cenderung turun, karena tidak sebanding antara jumlah tenaga kerja dengan penawaran tenaga kerja.

4. Teori Upah Etika

Menurut kaum Utopis (kaum yang memiliki idealis masyarakat yang ideal) tindakan para pengusaha yang memberikan upah hanya cukup untuk memenuhi kebutuhan minimum, merupakan suatu tindakan yang tidak "etis".Oleh karena itu sebaiknya para pengusaha selain dapat memberikan upah yang layak kepada pekerja dan keluarganya, juga harus memberikan tunjangan keluarga. Pendapatan adalah nilai maksimal yang dapat dikonsumsi oleh seseorang dalam suatu periode dengan mengharapkan keadaan yang sama pada akhir periode seperti keadaan semula, pendapatan merupakan balas jasa yang diberikan kepada pekerja atau buruh yang punya majikan tapi tidak tetap.

\section{Konsep Sektor Informal}

Istilah sektor informal biasanya digunakan untuk menunjukkan sejumlah kegiatan ekonomi yang berskala kecil. Namun kalangan akademisi masih memperdebatkan teori dan konsep mengenai sektor informal ini. Ada yang menganggap bahwa sektor informal muncul karena terbatasnya kapasitas industriindustri formal dalam menyerap tenaga kerja yang ada, sehingga terdapat kecenderungan bahwa sektor informal ini muncul di pinggiran kota besar. Sebagian yang lain menganggap bahwa sektor informal ini sudah lama ada. Ini adalah pandangan dari perspektif yang dualistik, yang melihat sektor informal dan formal sebagai dikotomi antara model ekonomi tradisional dan modern (Safira, $2003: 4$ ).

Istilah sektor sektor informal dipandang sebagai kekuatan yang semakin signifikan bagi perekonomian lokal dan global, seperti yang dicantumkan dalam pernyataan visi WIEGO (Woman In Informal Employment Globalizing and Organizing) yaitu mayoritas pekerja di dunia kini bekerja di sektor informal dan proporsinya terus membengkak sebagai dampak dari globalisasi: mobilitas capital, restrukturisasi produksi barang dan jasa, dan deregulasi pasar tenaga kerja mendorong semakin banyak pekerja ke sektor informal.( Safira, 2003:6).

Kegiatan usaha sektor informal merupakan kegiatan usaha kecil-kecilan dan merupakan lapangan pekerjaan yang sangat penting, khususnya bagi tenaga kerja yang tidak dapat di tampung pada sektor formal.Hal ini dikarenakan luasnya kesempatan yang tersedia di sektor ini, yang memungkinkan bagi individu untuk menciptakan lapangan pekerjaan bagi dirinya sendiri sesuai dengan kemampuannya.

Perbedaan antara sektor informal, dapat dilihat dari beberapa aspek sebagai berikut: 
Sentralisasi Volume 5(2): 1-14 (2016)

Determinan Kesempatan Kerja Pada Sektor Informal....

Arce Yulita Ferdinandus

1. Aspek produksi : pertanian di pengaruhi oleh musim, tidak dapat diperbesar seketika dipengaruhi oleh kesuburan tanah, dan sudah mendapatkan proteksi dari pemerintah, dalam sektor informal produksi dapat dilakukan sepanjang tahun, dapat diperbesar seketika, dipengaruhi tenaga kerja dan tidak mendapatkan proteksidari pemerintah.

2. Permodalan : dalam sektor pertanian, modal diperoleh dari pemerintah atau lembaga keuangan resmi, sedangkan dalam sektor informal modal berasal dari tabungan sendiri atau keuangan tidak resmi.

3. Aspek pemasaran: sektor pertanian merupakan konsumsi rumah tangga dan industri harga lebih stabil serta ada bantuan dari pemerintah, sedangkan sektor informal merupakan konsumsi rumah tangga golongan bawah atau menengah harga relativ tidak stabil serta tidak ada bantuan pemerintah.

4. Aspek organisasi: dalam sektor pertanian pada umumnya kegiatan sudah bergabung dalam organisasi, sedangkan kegiatan dalam sektor informal tidak terorganisasi.

5. Aspek pekerjaan: pekerjaan dalam bidang pertanian pada umumnya bersifat multi karya serta banyak terdapat pengangguran tidak kentara disamping itu pekerjaan dalam bidang pertanian tidak memerlukan ketrampilan khusus, dalam sector informal kegiatan usaha bersifat swakarya, ralatif tidak terdapat pengangguran terselubung serta diperlukan ketrampilan khusus.

Perekonomian disektor informal relative dapat lebih mandiri. Karena pertumbuhan disektor formal secara langsung memperbaiki kesejateraan golongan ekonomi lemah, maka kemajuan dalam sektor informal sekaligus menaikan pendapatan nasional (meskipun tidak banyak), dan memperbaiki distribusi pendapatan. Bila di sektor formal kurangnya permintaan dapat menyebabkan kelesuan perekonomian di sector informal permintaan akan selalu kuat, sebab barang dan jasa yang dihasilkan sektor ini merupakan barang dan jasa yang dibutuhkan masyarakat sehari-hari.

Perilaku sektor formal yang kikir dalam penyerapan tenaga kerja, justru membawa dampak positif bagi sektor informal. Bagaimana tidak, sektor informal diharapkan dapat menjadi sektor yang dapat menyerap angka pengangguran yang cukup besar. Pertumbuhan ekonomi tidak sanggup menanggapi surplus tenga kerja yang muncul sejak awal pertumbuhan ekonomi. Perekonomian di sektor informal relative dapat lebih mandiri.Karena pertumbuhan di sektor informal secara langsung memperbaiki kesejahtraan golongan ekonomi lemah, maka kemajuan dalam sektor informal sekaligus menaikan pendapatan nasional (meskipun tidak banyak), dan memperbaiki distribusi pendapatan. Bila di sektor formal kurangnya permintaan dapat menyebabkan kelesuan perekonomian, di sektor informal permintaan akan selalu kuat, sebab barang dan jasa yang dihasilkan di sektor ini merupakan barang dan jasa yang dibutuhkan masyarakat sehari-hari (Mulyadi, 2003 : 86).

Kegiatan sektor informal yang menonjol biasanya terjadi di kawasan yang sangat padat penduduknya, dimana pengangguran (unemployment) maupun pengangguran terselubung (disquised unemployment) merupakan masalah yang utama. Dengan kenyataan seperti ini limpahan tenaga kerja masuk ke dalam sektor informal, tetapi masih dipandang sebagai penylesaian sementara karena di dalam sektor informal sendiri terdapat persoalan yang sangat rumit.

\section{Perbedaan Sektor Formal dan Sektor Informal}

Sektor formal atau sektor modern mencakup perusahaan-perusahaan yang mempunyai status hukum, pengakuan dan izin resmi, umumnya berskala besar. Sebaliknya usaha-usaha yang tergolong sector informal antara lain sebagai berikut: 
1. Kegiatan usaha umumnya sederhana, tidak sangat tergantung pada kerja sama banyak orang dan sistem pembagian kerja yang ketat. Dengan demikian dapat dilakukan oleh perorangan atau keluarga, atau usaha bersama antara beberapa orang atas kepercayaan tanpa perjanjian tertulis.

2. Skalah usaha relatif kecil. Model usaha, modal kerja dan omset penjualan umumnya kecil. Serta dapat dilakukan secara bertahap.

3. Usaha sektor informal umumnya tidak mempunyai izin usaha seperti halnya dalam bentuk firma atau perusahaan terbatas.

4. Sebagai akibat dari hal pertama, kedua dan ketiga diatas, untuk bekerja disektor informal lebih mudah dari pada bekerja di perusahaan formal. Seseorang dapat memulai dan melakukan sendiri usaha di sektor informal asal Dia mempunyai keinginan dan kesediaan untuk itu. Seseorang relatif lebih mudah bergabung bekerja dengan orang lain di sector informal, misalya karena persahabatan atau hubungan keluarga, walaupun keikutsertaan seseorang mungkin tidak lagi menabah hasil keseluruhan.

5. Tingkat penghasilan di sektor informal umumnya rendah walaupun tingkat keuntungan kadang-kadang cukup tinggi, akan tetapi nkarena omset penjualan relatif kecil, keuntungan absolut umunya menjadi kecil.

6. Keterkaitan sector informal dengan usaha-usaha lain sangat kecil. Kebanyakan usaha-usaha sector informal berfungsi sebagai produsen atau penyalur kecil yang langsung melayani konsumen. Pendeknya jalur tersebut justru membuat resiko usaha menjadi relative besar, dan sangat terpengaruh pada perubahan-perubahan yang terjadi pada konsumen.
7. Usaha sektor informal sangat beraneka ragam seperti pedagang kaki lima, pedagang keliling, tukang warung, sebagian tukang cukur, sebagian tukang becak, sebagian tukang sepatu, tukang loak, serta usaha-usaha rumah tangga seperti pembuat tempe pembuat kue, pembuat es mambo, barang anyamanyaman, tukang jahit, tukang tenun dan lain-lain. Lebih dari 60 persen angkatan kerja Indonesia dewasa ini terserap di sektor informal.

\section{Modal}

Modal adalah sejumlah uang yang digunakan untuk mengelola dan membiayai usaha setiap bulan/ setiap hari. Dimana di dalamnya terdapat ongkos untuk pembelian sumber-sumber produksi yang digunakan untuk memproduksi suatu out put tertentu/opportunity cost dan untuk menggunakan input yang tersedia. Kemudian di dalam ongkos juga terdapat hasil atau pendapatan bagi pemilik modal yang besarnya sama dengan seandainya dalam usaha menanamkan modalnya di dalam sector ekonomi lainnya dan pendapatan untuk tenaga kerja sendiri. Sehingga keuntungan merupakan hal yang sangat berat bagi seorang yang bergerak disektor informal. (Efriana, 2012 $: 3)$.

\section{Rumusan Masalah}

Berdasarkan keseluruhan uraian latar belakang diatas dapat dirumuskan permasalahan sebagai berikut :

1. Apakah upah berpengaruh terhadap tingkat kesempatan kerja pada sektor informal di kota Ambon.

2. Apakah pengalaman usaha dalam sektor informal mempengaruhi kesempatan kerja pada sektor informal di kota Ambon.

3. Apakah modal usaha dalam sektor informal mempengaruhi kesempatan kerja di sektor informal di kota Ambon. 


\section{Tujuan Penelitian}

1. Untuk mengetahui bagaimana pengaruh upah terhadap kesempatan kerja pada sektor informal di Kota Ambon.

2. Untuk mengetahui bagaimana pengaruh pengalaman usaha dalam sektor informal terhadap kesempatan kerja pada sektor informal di Kota Ambon.

3. Untuk mengetahui bagamana pengaruh modal usaha dalam sektor informal terhadap kesempatan kerja pada sektor informal di Kota Ambon.

\section{ManfaatPenelitian}

Penelitian ini dapat memberikan manfaat sebagai berikut :

1. Hasil penelitian ini diharapkan memberikan informasi tentang keadaan kesempatan kerja pada sektor informal di Kota Ambon.

2. Penelitian ini bermanfaat sebagai bahan rujukan bagi pengambilan kebijakan pada sektor informal di Kota Ambon.

3. Sebagai masukan bagi pemerintah Kota Ambon dalam menentukan kebijakan mengenai perkembangan sektor informal dalam meningkatkan kesejahteraan rakyat di Kota Ambon, serta menjadi informasi berguna bagi akademisi di bidang Regional Science.

4. Sebagai masukan bagi pelaku bisnis di sektor informal dalam mengembangkan usahanya sehingga mampu bersaing.

5. Sebagai tambahan referensi bagi penelitian tentang sektor informal.

\section{METODE PENILITIAN}

\section{Lokasi dan Waktu Penilitian}

Penelitian ini dilakukan di Kota Ambon. Selain itu juga dilakukan pengambilan data sekunder melalui Badan Pusat Statistik (BPS), Dinas Nekertrans, dan Dinas Perindustrian dan Perdagangan di Kota Ambon. Sedangkan waktu yang dibutuhkan dalam penelitian ini adalah \pm 3 Bulan.

\section{Populasi dan Sampel}

Sulistyo-Basuki

mengemukakan populasi adalah keseluruhan objek yang akan diteliti. Populasi dalam penelitian ini adalah seluruh sektor informal yang ada di Kota Ambon.

Menurut Sugiono (1999 : 74) "Sampel dalam penelitian ini menggunakan Simple Random Sampling dikatakan simple (sederhana) karena pengambilan sampel anggota populasi dilkukan secara acak tanpa memperhatikan strata yang ada dalam populasi itu.cara demikian dilakukan bila anggota populasi dianggap homogen.

\section{Jenis dan Sumber Data}

Berdasarkan sumbernya, sumber data umumnya berasal dari (Hanke dan Reitsch, 1998: bab 3 dalam Kuncoro, 2007) :

- Data internal (berasal dari dalam organisasi tersebut) atau eksternal (berasal dari luar organisasi).

Data primer atau data sekunder. Data primer biasanya diperoleh dengan survey lapangan yang menggunakan semua metode pengumpulan data original.

\section{Metode Analisis}

a. Analisis Regresi

Analsis yang digunakan dalam penelitian ini yaitu analisis regresi linier berganda dengan metode kuadrat terkecil biasa (Ordinary Least-Square).

Secara matematis model tersebut dapat dituliskan sebagai berikut :

$$
\mathrm{L}_{\mathrm{n}} \mathrm{Y}=\beta_{0+} \beta_{1} \mathrm{~L}_{\mathrm{n}} \mathrm{X}_{1}+\beta_{2} \mathrm{~L}_{\mathrm{n}} \mathrm{X}_{2}+\beta_{3} \mathrm{~L}_{\mathrm{n}} \mathrm{X}_{3}+
$$
$\mu$

Dimana : 


$\begin{array}{ll}\mathrm{Y} & =\text { kesempatankerja } \\ \beta_{0} & =\text { Konstanta } \\ \beta_{1}, \beta_{2}, \beta_{3} & =\text { koefisien } \\ \mathrm{X}_{1} & =\text { Upah } \\ \mathrm{X}_{2} & =\text { jenis usaha sektor } \\ \text { informal } & \\ \mathrm{X}_{3} & =\text { Modal } \\ \mu & =\text { Faktor Pengganggu }\end{array}$

b. Analisis Deskriptif

Dalam penelitian ini juga digunakan analisis deskriptif untuk menggambarkan kondisi-kondisi pada sektor Informal di Kota Ambon yang ditemukan di lapangan yaitu pendidikan tenaga kerja yang terserap, jenis kelamin tenaga kerja yang diserap, dan jenis usaha yang dihasilkan.

Adapun pengujian yang dilakukan yaitu :

1. Uji penyimpangan Asumsi Klasik, terdiri dari :

Uji Normalitas,

Uji Multikolinieritas,

Uji Auto Korelasi,

Uji Heteroskedastisitas

2. Pengujian Statistik Analisa Regresi, terdiri dari :

a. Koefisien Determinasi $\left(\mathrm{R}^{2}\right)$ dilakukan untuk mengetahui besarnya pengaruh faktor-faktor secara bersama-sama $\mathrm{R}^{2}$ menunjukan besarnya variasi sumbangan variable bebas dan variabel tidak bebas.

b. Uji Signifikansi Simultan (Uji F) digunakan untuk mengetahui ada tidaknya pengaruh upah, jenis usaha sektor informal dan modal secara simultan atau secara bersamasama terhadap kesempatan kerja.

c. Uji Signifikansi Parameter Individual (Uji t) untuk mengetahui ada tidaknya pengaruh upah, jenis usaha sektor informal dan modal secara parsial atau sendiri-sendiri terhadap kesempatan kerja.

\section{Profil Responden}

Jumlah 80 responden yang di pakai untuk menganalisa data terdiri dari jenis usaha di sektor jasa 40 responden terdiri 12 orang responden perempuan (15\%) dan responden laki-laki 28 orang $(35 \%)$. Sedangkan jenis usaha disektor perdagangan 40 responden terdiri dari 13 orang perempuan $(33,75 \%)$ dan responden laki-laki $27(33,78 \%)$.

Tingkat pendidikan terbanyak responden, terdiri dari 5 orang responden lakilaki pada tingkat SD (23,75\%), tingkat SMP responden laki-laki 19 orang $(36,75 \%)$ dan responden perempuan 8 orang $(10 \%)$, tingkat SMA/SMK responden laki-laki 29 orang $(13,63 \%)$ dan responden perempuan 17 orang $(21,25 \%)$, tingkat Universitas responden lakilaki 3 orang $(3,75 \%)$.

Jenis usaha masing-masing responden jasa, responden laki-laki 28 orang $(35 \%)$ dan responden perempuan 12 orang (15\%). Sedangkan perdagangan, responden laki-laki 27 orang $(33,75 \%)$ dan responden perempuan 13 orang $(16,25 \%)$.

\section{Data Demografi Responden}

Tabel

Data Demografi Responden 


\begin{tabular}{|l|c|c|c|c|c|c|}
\hline \multicolumn{1}{|c|}{ Keteranagan } & $\begin{array}{r}\text { La } \\
\text { ki- } \\
\text { Laki }\end{array}$ & $\%$ & $\begin{array}{c}\text { Peremp } \\
\text { uan }\end{array}$ & $\%$ & Total & $\%$ \\
\hline 1.Jenis Kelamin & 59 & 3,75 & 21 & $\begin{array}{c}16, \\
8\end{array}$ & 80 & - \\
\hline 2.Tingkat & - & - & - & - & - & - \\
$\begin{array}{l}\text { Pendidikan : } \\
\text { a. tidak sekolah } \\
\text { formal }\end{array}$ & 3 & 23,75 & - & - & 3 & 3,75 \\
$\quad 19$ & 36,75 & 8 & 10 & 27 & 33,75 \\
b. SD & 30 & 13,63 & 17 & 21, & 47 & 58,75 \\
c. SMP & 3 & 3,75 & - & 25 & 3 & 3,75 \\
$\quad \begin{array}{l}\text { d.SMA/SMK } \\
\text { e. Universitas }\end{array}$ & & & & - & & \\
\hline $\begin{array}{l}\text { 3. Jenis Usaha: } \\
\text { a. Jasa }\end{array}$ & 28 & 35 & 12 & 15 & 40 & 50 \\
$\quad$ b. Perdagangan & 27 & 33,75 & 13 & 16, & 40 & 50 \\
\hline
\end{tabular}

Sumber : Data Penelitian tahun 2015

\section{statistic Descriptif}

Descriptive Statistics

\begin{tabular}{|c|c|c|c|c|c|c|c|c|c|c|}
\hline & \multirow{2}{*}{$\begin{array}{l}\mathrm{N} \\
\\
\text { Sta } \\
\text { tist } \\
\text { ic }\end{array}$} & \multirow{2}{*}{$\begin{array}{l}\mathrm{Mi} \\
\mathrm{ni} \\
\mathrm{mu} \\
\mathrm{m} \\
\text { Sta } \\
\text { tist } \\
\text { ic }\end{array}$} & \multirow{2}{*}{$\begin{array}{c}\text { Ma } \\
\text { xi } \\
\text { mu } \\
\mathrm{m} \\
\text { Sta } \\
\text { tist } \\
\text { ic }\end{array}$} & \multicolumn{2}{|c|}{ Mean } & \multirow{2}{*}{$\begin{array}{c}\begin{array}{c}\text { Std. } \\
\text { Devia } \\
\text { tion }\end{array} \\
\begin{array}{c}\text { Statist } \\
\text { ic }\end{array}\end{array}$} & \multicolumn{2}{|c|}{ Skewness } & \multicolumn{2}{|c|}{ Kurtosis } \\
\hline & & & & $\begin{array}{c}\text { Sta } \\
\text { tist } \\
\text { ic }\end{array}$ & $\begin{array}{c}\text { Std } \\
\text { Err } \\
\text { or }\end{array}$ & & $\begin{array}{l}\text { Sta } \\
\text { tist } \\
\text { ic }\end{array}$ & $\begin{array}{l}\text { Std } \\
\text { Err } \\
\text { or }\end{array}$ & Statistic & $\begin{array}{c}\text { Std. } \\
\text { Error }\end{array}$ \\
\hline $\begin{array}{c}\text { Modal } \\
\text { X3 }\end{array}$ & 80 & 10 & 15 & $\begin{array}{l}11 . \\
92\end{array}$ & $\begin{array}{r}0.1 \\
22\end{array}$ & 1.088 & $\begin{array}{c}0.7 \\
56\end{array}$ & $\begin{array}{r}0.2 \\
69\end{array}$ & 2.662 & 0.532 \\
\hline Upah & & & & 13. & 0.2 & & 0.0 & 0.2 & & \\
\hline $\begin{array}{c}\mathrm{X} 1 \\
\text { Pengala } \\
\text { man }\end{array}$ & 80 & 10 & 18 & 6 & 14 & 1.913 & 48 & 69 & -0.814 & 0.532 \\
\hline $\begin{array}{c}\text { Usaha } \\
\text { X2 }\end{array}$ & 80 & 13 & 24 & $\begin{array}{l}18 . \\
98\end{array}$ & $\begin{array}{r}0.3 \\
16\end{array}$ & 2.828 & $\begin{array}{r}0.4 \\
73\end{array}$ & $\begin{array}{r}0.2 \\
69\end{array}$ & -0.165 & 0.532 \\
\hline $\begin{array}{c}\text { Kesemp } \\
\text { atan }\end{array}$ & & & & 12. & 0.1 & & $0 . \overline{5}$ & 0.2 & & \\
\hline $\begin{array}{l}\text { Kerja Y } \\
\text { Valid N } \\
\text { (listwise }\end{array}$ & 80 & 9 & 15 & 11 & 63 & 1.458 & 27 & 69 & -0.119 & 0.532 \\
\hline
\end{tabular}

Sumber: Output Pengolahan Data Dengan SPSS

Dari tabel diatas dapat dilihat bahwa variabel X1 dengan sampel $(\mathrm{N})$ sebanyak 80 memiliki nilai minimum 10 , nilai maksimum 18 , rata-rata sebesar 13.60 dan standar deviasinya sebesar 1.913. variabel $\mathrm{X} 2$ sampel $(\mathrm{N})$ sebanyak 80 memiliki nilai minimum 13 , nilai maksimum 24 , rata-rata sebesar 18.98 dan standar deviasinya sebesar 2.828. variabel X3 sampel (N) sebanyak 80 memiliki nilai minimum 10 , nilai maksimum 15, rata-rata sebesar 11.92 dan standar deviasinya sebesar 1.088. variabel $\mathrm{Y}$ sampel (N) sebanyak 80 memiliki nilai minimum 9, nilai maksimum 15 , rata-rata sebesar 12.11 dan standar deviasinya sebesar 1.458 .

\section{HASIL DAN PEMBAHASAN}

Dari tabel diatas dapat dilihat bahwa variabel X1 dengan sampel $(\mathrm{N})$ sebanyak 80 memiliki nilai minimum 10, nilai maksimum 18, rata-rata sebesar 13.60 dan standar deviasinya sebesar 1.913. variabel X2 sampel (N) sebanyak 80 memiliki nilai minimum 13 , nilai maksimum 24 , rata-rata sebesar 18.98 dan standar deviasinya sebesar 2.828. variabel X3 sampel (N) sebanyak 80 memiliki nilai minimum 10, nilai maksimum 15, rata-rata sebesar 11.92 dan standar deviasinya sebesar 1.088. variabel $\mathrm{Y}$ sampel (N) sebanyak 80 memiliki nilai minimum 9, nilai maksimum 15 , rata-rata sebesar 12.11 dan standar deviasinya sebesar 1.458 .

\section{Pengaruh Tingkat Upah Terhadap Kesempatan Kerja}

Berdasarkan hipotesis pertama (H1) yang telah di rumuskan dalam penelitian ini bahwa variabel tingkat upah dalam sektor informal khususnya perdagangan dan jasa berpengaruh positif terhadap kesempatan kerja pada sektor informal di Kota Ambon. Namun, hipotesis pertama (H1) tidak sesuai dengan hasil analisis statistik dalam penelitian ini ditemukan bahwa variabel tingkat upah secara parsial memiliki pengaruh yang positif dan signifikan terhadap kesempatan kerja di Kota Ambon. Dibuktikan pada hasil Uji Regresi yang menunjukan nilai signifikansi $0.006<0.05$.

Nilai Uji Regresi telah menbuktikan bahwa variabel tingkat upah sangat berpengaruh yang positif dan signifikan terhadap kesempatan kerja, dengan begitu variabel tingkat upah yang 
berbanding terbalik dengan kesempatan kerja yang tersedia di Kota Ambon. Dikarenakan sektor informal memberikan peluang kerja dan pendapatan yang mencukupi kebutuhan per hari bagi setiap pekerja sehingga besar kecilnya upah yang diperoleh tidak memberikan pengaruh negatif terhadap kesempatan kerja yang tersedia.

Seperti halnya menurut Payaman Simanjuntak, 2002 bahwa kenaikan tingkat upah akan diikuti oleh turunnya tenaga kerja yang diminta, yang berarti akan menyebabkan bertambahnya jumlah pengangguran. Demikian pula sebaliknya, dengan turunnya tingkat upah maka akan diikuti oleh meningkatnya kesempatan kerja, sehingga akan dikatakan bahwa kesempatan kerja mempunyai hubungan terbalik dengan tingkat upah. Kenaikan tingkat upah yang disertai oleh penambahan tenaga kerja hanya akan terjadi bila suatu perusahaan mampu meningkatkan harga jual barang, hal ini terjadi pada sektor formal namun tidak berlaku pada sektor informal.

Dengan demikian dapat disimpulkan bahwa tingkat upah dalam sektor informal khususnya perdagangan dan jasa memiliki pengaruh yang sangat positif dan signifikan terhadap kesempatan kerja di Kota Ambon. Jadi hipotesis pertama (H1) ditolak secara statistik.

\section{Pengaruh Jenis Usaha Terhadap Kesempatan Kerja}

Berdasarkan hipotesis kedua $(\mathrm{H} 2)$ yang telah di rumuskan dalam penelitian ini bahwa variabel jenis usaha dalam sektor informal khususnya perdagangan dan jasa berpengaruh positif terhadap kesempatan kerja pada sektor informal di Kota Ambon. Maka, hipotesis kedua (H2) sangatlah sesuai dengan hasil analisis statistik dalam penelitian ini ditemukan bahwa variabel jenis usaha secara parsial memiliki pengaruh yang sangat positif dan signifikan terhadap kesempatan kerja di Kota Amobon. Dibuktikan pada hasil Uji Regresi yang menunjukan nilai signifikansi $0.000<0.05$.
Nilai Uji Regresi telah menbuktikan bahwa variabel jenis usaha dalam sektor informal khususnya perdagangan dan jasa sangat berpengaruh yang positif dan signifikan terhadap kesempatan kerja, dengan begitu kesempatan kerja sangatlah tergantung dari jenis usaha yang tersedia di Kota Ambon. Jenis usaha di Kota Ambon dalam sektor infromal berkembang pesat mendorong terciptanya kesempatan kerja.

Seperti halnya menurut Azis Prabowo (1997), yang menyatakan bahwa pengaruh yang diberikan jumlah dan jenis unit usaha terhadap penyerapan tenaga kerja positif dan signifikan, karena adanya pendirian unit usaha dan jenis usaha yang beragam di sektor informal dapat menyerap banyak tenaga kerja karena mulai membaiknya keadaan perekonomian setelah krisis ekonomi. Hal ini sesuai dengan teori bahwa dengan membaiknya perekonomian, maka keadaan perekonomian juga menjadi stabil dan merupakan keadaan yang kondusif bagi tumbuhnya unit usaha baru. Begitu juga sebaliknya, dengan semakin memburuknya perekonomian maka banyak unit usaha atau perusahaan yang gulung tikar atau bangkrut, sehingga akan menurun pula jumlah unit usaha dan jesih usaha yang ada dan pada akhirnya akan menurunkan jumlah tenaga kerja yang diminta. Dengan demikian dapat disimpulkan bahwa jenis usaha dalam sektor informal khususnya perdagangan dan jasa memiliki pengaruh yang sangat positif dan signifikan terhadap kesempatan kerja di Kota Ambon. Jadi hipotesis kedua (H2) diterima secara statistik.

\section{Pengaruh Modal Terhadap Kesempatan Kerja}

Berdasarkan hipotesis ketiga (H3) yang telah di rumuskan dalam penelitian ini bahwa variabel modal usaha dalam sektor informal khususnya perdagangan dan jasa berpengaruh negatif terhadap kesempatan kerja pada sektor informal di Kota Ambon. Namun, hipotesis ketiga (H3) dengan hasil analisis statistik dalam 
penelitian ini ditemukan bahwa variabel modal usaha secara parsial memiliki pengaruh tidak signifikan terhadap kesempatan kerja di Kota Amobon. Dibuktikan pada hasil Uji Regresi yang menunjukan nilai signifikansi $0.072>$ 0.05 .

Nilai Uji Regresi telah menbuktikan bahwa variabel modal usaha tidak berpengaruh secara signifikan terhadap kesempatan kerja. Dikarenakan seluruh usaha pada sektor informal pada awal memulai usaha tidak membutuhkan modal besar dalam mengembangkan usaha tidak seperti usaha - usaha pada sektor formal yang membutuhkan modal besar dengan diikuti meningkatnya penyerapan tenaga kerja, sehingga kesempatan kerja yang tersedia pada awal usaha di sektor informal tidak dipengaruhi oleh modal usaha.

\section{KESIMPULAN}

Berdasarkan analisis di atas dapat kita simpulkan bahwa variabel tingkat upah, jenis usaha dan modal dalam usaha perdagangan dan jasa pada sektor informal memiliki pengaruh yang signikan dan berbeda terhadap kesempatan kerja di Kota Ambon. Ini terlihat dari hasil analisis statistik dengan nilai signifikan yang berbeda dari masing - masing variabel terhadap kesempatan kerja pada perdagangan dan jasa di sektor informal di Kota Ambon. Hal ini dapat diuraikan sebagai berikut; dimana, variabel tingkat upah berpengaruh positif dan signifikan terhadap kesempatan kerja pada perdagangan dan jasa di sektor informal. Hal ini menunjukkan bahwa tinggi rendahnya upah yang diberikan pada sektor informal tidak memberikan pengaruh negatif bagi kesempatan kerja.sehingga variabel jenis usaha dari hasil analisi statistik juga memberikan pengaruh positif dan signifikan terhadap kesempatan kerja pada perdagangan dan jasa di sektor informal. Hal ini menunjukkan bahwa semakin banyak jenis usaha pada sektor informal memberikan manfaat baik bagi terciptanya kesempatan kerja. Sedangkan variabel modal usaha sendiri tidak berpengaruh signifikan terhadap kesempatan kerja pada perdagangan dan jasa di sektor informal. Hal ini menunjukkan bahwa modal awal yang digunakan untuk memulai usaha pada sektor informal tidak mempengaruhi kesempatan kerja.

\section{DAFTAR PUSTAKA}

Dinas Tenaga Kerja Dan Transmigrasi Provinsi Maluku, 2012.
Mulyadi S., 2003. Ekonomi Sumber Daya Manusia dalam prespektif pembangunan.PT Raja Grafindo Persada, Jakarta.

Mankiw. N. Gregory, 2003. Teori Makro Ekonomi. Erlangga, Jakarta

Mankiw. N. Gregory, 2006. Teori Makro Ekonomi. Erlangga, Jakarta

Payaman. J. Simanjuntak, 2001. Pengantar Ekonomi sumber Daya Manusia.Fakultas Ekonomi Universitas Indonesia, Jakarta.

Payaman. J. Simanjuntak, 1998. Pengantar Ekonomi sumber Daya Manusia. Fakultas Ekonomi Universitas Indonesia,edisi ke-2 Jakarta 